\title{
Using Entrepreneurial Marketing to Foster Reseller Adoption of Smart Micro-Grid Technology
}

\author{
Hamidreza Kavandi and Mika Westerlund
}

\author{
"Benjamin Franklin may have discovered electricity, but it" \\ was the man who invented the meter who made the money. \\ Earl Warren (1891-1974) \\ Politician and Chief Justice of the United States
}

\begin{abstract}
This article investigates how entrepreneurial marketing can encourage resellers to adopt smart micro-grid technology. An online survey based on the literature on user adoption and entrepreneurial marketing was used to gather data from 99 power systems resellers. The data were analyzed using the partial least squares method to validate a model of the relationships between reseller's antecedents and intention to adopt smart micro-grid technology, and the role of vendor's entrepreneurial marketing in the adoption. The results suggest that user adoption models can only partially be applied to the reseller context, and future research should develop models that can further explain reseller's decision making with regards to becoming involved in an emerging technology. As to the implications for practice, vendors need to demonstrate proactive entrepreneurial marketing, particularly entrepreneurial orientation, to increase the performance expectancy perceived by their resellers by increasing awareness and understanding of smart micro-grid technology to cultivate its diffusion.
\end{abstract}

\section{Introduction}

The growing demand for electricity and the environmental impact of energy generation impose major challenges for the energy industry. At the same time, smart grid technology represents an emerging field of power systems that allows for better management of interconnected loads and alternative and renewable energy resources than the traditional power systems technologies. A smart micro-grid is a small-scale, intelligent power system based on the smart grid technology, and it has advanced energy generation, transmission, distribution, consumption, and metering elements, and machine-to-machine communication ability. Smart micro-grid solutions utilize two-way flow of electricity and communications to enhance reliability, efficiency, security, quality, and sustainability of local energy supply (Fang et al., 2012). However, in spite of the benefits that smart micro-grid technology provides, it has not been widely adopted in the market (Luthra et al., 2014), and existing research into smart micro-grid technology is limited to a technical perspective (Cardenas et al., 2014; Saxena, 2014). There is a need to understand the market adoption of smart micro-grid technology, especially as it relates to resellers who act as intermediaries between technology vendors and end users.

Although there is ample research on technology marketing strategies, the role of vendors' marketing to resellers is largely neglected (Westerlund \& Rajala, 2014). Vendors of smart micro-grids include both small firms that make or add smart technology into power system utilities and large technology providers such as Siemens, Schneider, or Alstom Power. Resellers include energy retailers such as Direct Energy and renewable energy equipment retailers such as Solpowered Energy Corporation. Resellers target end users who are businesses, residential communities, and individuals that want to ensure energy supply in times of power outages. Giordano and Fulli (2012) discuss the actions that can improve the consumer value proposition in power systems technology and enhance consumer engage- 


\section{Entrepreneurial Marketing to Foster Reseller Adoption of Smart Micro-Grid Technology} Hamidreza Kavandi and Mika Westerlund

ment in energy efficiency. However, prior studies have not focused on reseller intentions or decision making with regards to becoming involved in a technology, nor how the vendor might advance these intentions. Thus, there is a research gap on the topic of why resellers adopt specific technology for modification and reselling purposes, and how vendors can encourage this adoption through entrepreneurial marketing. Entrepreneurial marketing is considered more proactive, more innovative, more opportunity and growth oriented, and more willing to take risks than conventional marketing (Hills \& Hultman, 2011).

This research introduces a conceptual model based on the literature for user acceptance and entrepreneurial marketing to understand the relationships between smart micro-grid technology drivers and technology adoption by resellers, as well as the role of entrepreneurial marketing by vendors in those relationships. Previous research typically applies technology and user acceptance models to the end-user context (e.g., Venkatesh et al., 2012); there are few models available that would explain technology choices of resellers (Westerlund, \& Rajala, 2014). Entrepreneurial marketing by vendors is understood as a combination of strategic orientations (cf. Jones \& Rowley, 2011), which act as potential moderators in the relationships between smart micro-grid technology and the reseller's intention to adopt such technology. The model is tested using survey data from power systems technology resellers through the partial least squares analysis, a form of structural equation modelling, which is effective for predictive behavioural models (cf. Lowry \& Gaskin, 2014).

The article is structured as follows. After this introduction, we review the literature on user acceptance and entrepreneurial marketing. Then, we present a conceptual model with hypotheses on the relationships between the drivers of smart micro-grid technology adoption and a reseller's intention to adopt such technology, as well as the role of entrepreneurial marketing by vendors in those relationships. Thereafter, we summarize the methodology and results from the analysis. Finally, we conclude by describing the implications of the results for theory and practice.

\section{Literature Review}

\section{User adoption to reseller adoption}

The technology acceptance model is the most widely used model for understanding the adoption of technology (Benbasat \& Barki, 2007), because it is contextually versatile and provides proven measures to predict user adoption of any given product, service, or system (Venkatesh et al., 2003). The technology acceptance model was developed to understand an individual's adoption of information technology, therefore it has two fundamental elements: i) perceived usefulness, or the degree to which an individual believes using the system would enhance their job performance, and ii) perceived ease of use, or the degree to which an individual believes using the system would be free of physical or mental effort (Davis, 1989). These two elements are individual reactions to using information technology, and they have been shown to influence an individual's intention to use the technology, and ultimately, the actual use (Venkatesh et al., 2003)

Despite the vast popularity of the technology acceptance model in research on information systems, there has been criticism against the model. For instance, Benbasat and Barki (2007) argue that the intense focus on the model has led to: i) the diversion of researchers' attention away from important phenomena such as the antecedents of user's beliefs or the consequences of adoption; ii) the creation of an illusion of progress in knowledge accumulation; iii) the inability to expand and adapt the core model to rapidly evolving technology adoption contexts; and iv) a state of theoretical confusion and chaos arising from efforts to modify and apply the model to evolving IT contexts, where the adaptations have not been based on solid and commonly accepted foundations. Furthermore, Ozaki (2009) notes that people decide to adopt an innovation not only because they see functionality, usability, or reasonable costs, but also because they are interested in the way the innovation reflects their identity, image, memberships, values, beliefs, and norms.

The scholarly community has invested significant resources and research effort in revising the technology acceptance model to meet the changing technological landscape, but these developments have brought us back full circle to the models origins (Benbasat \& Barki, 2007). Venkatesh, Morris, and Davis (2003) introduced one of the most notable revised models - the unified theory of acceptance and use of technology (UTAUT) using four explicit antecedents that affect a user's behavioural intention to adopt technology: performance expectancy, effort expectancy, social influence, and facilitating conditions. The model also includes implicit elements of an attitude toward using technology, selfefficacy, and anxiety. Later, Venkatesh, Thong, and $\mathrm{Xu}$ (2012) presented an improved model (UTAUT2) by adding three explicit antecedents: hedonic motivation, price value, and habit. Besides putting forward revised 


\section{Entrepreneurial Marketing to Foster Reseller Adoption of Smart Micro-Grid Technology} Hamidreza Kavandi and Mika Westerlund

antecedents of adoption, both UTAUT models emphasize the role of factors that moderate adoption, such as demographics and experience.

Whereas technology adoption has been extensively studied in the end-user context (cf. Benbasat \& Barki, 2007), there are few studies focused on the adoption of technology in the channel context, particularly with respect to resellers (Osmonbekov, 2010; Westerlund \& Rajala, 2014). We find this lack of research surprising given that resellers are key intermediaries between vendors and end-customers (Chung et al., 2012) and that one of the most effective ways to diffuse innovations to markets is to leverage the power of downstream channels (Sreenivas \& Srinivas, 2008). However, user acceptance models may not be applicable when studying reseller adoption, given that they have been designed for the individual context and resellers may emphasize dissimilar aspects when choosing technologies to adopt for modifying and reselling purposes. Then again, channel intermediaries may also be end users of emerging technology, and user acceptance models are known to have high predictive power (Benbasat \& Barki, 2007). In this study, the reseller's technology adoption model builds on four elements derived from UTAUT and UTAUT2 (Venkatesh et al., 2003; Venkatesh et al., 2012): performance expectancy, effort expectancy, facilitating conditions, and price value.

\section{Entrepreneurial marketing}

Marketing is a critical activity that plays an important role in a company's success (Franco et al., 2014). Entrepreneurial marketing is a field of marketing associated with entrepreneurial behaviour and small firm resources and practices that are based on effectuation rather than causation (Mort et al., 2012). The entrepreneurial marketing construct has evolved as a response to contemporary market conditions where creative, nonstandard solutions are required to address the complex, chaotic, and fragmented nature of the business environment (Fillis, 2010). Entrepreneurial marketing describes the marketing processes of firms pursuing opportunities in uncertain market circumstances (Becherer et al., 2008), and it is used as the proactive exploitation of opportunities for acquiring and retaining profitable customers through innovative approaches to risk management, resource leveraging, and value creation (Morris et al., 2002). Exploitation of opportunities requires rapid market learning and perseverance in the face of obstacles and the ability to take advantage of unexpected events (Mort et al., 2012) to overcome initial market barriers (Franco et al., 2014).
Both marketing and entrepreneurship are change focused, opportunistic in nature, and innovative in their approach (Collinson \& Shaw, 2001). They both acknowledge the importance of opportunity recognition (Miles et al., 2015). However, entrepreneurial marketing is distinct from conventional marketing: rather than relying on the traditional 4Ps of marketing (product, price, place, and promotion), entrepreneurial marketing emphasizes the entrepreneurial 4Ps (purpose, practice, process, and people) (Martin, 2009). Entrepreneurial marketing outcomes comprise innovation and customer value (Jones et al., 2013) through firms' proactive, innovative, risky, and opportunity- and growth oriented actions (Hills \& Hultman, 2011). For example, fast growth technology companies use new approaches, interactive processes and networks to promoting and selling innovations (Jones et al., 2013), and tend to have long-term orientation to opportunity creation and exploitation (Hills et al., 2008). Hence, the previous literature (e.g., Morris et al., 2002; Jones \& Rowley, 2011; Ahmadi \& O'Cass, 2015) views entrepreneurial marketing as a combination of strategic orientations. Taken together, the key orientations are customer orientation, entrepreneurial orientation, and innovation orientation.

Customer orientation refers to the importance of employees being customer-focused and close to customers, meaning they are well positioned to address customer needs and wants. Customer orientation has three dimensions: i) responsiveness toward customers, ii) communication with customers, and iii) understanding and delivering customer value (Jones \& Rowley, 2011). The first dimension, responsiveness towards customers, means employee/corporate responsiveness to customer feedback and how fast the reaction can shift to customer preferences (Jones \& Rowley, 2011). The second dimension, communication with customers, refers to a policy of frequent customer feedback and mechanisms to build long-term customer relationships; entrepreneurial marketing calls for increasing the reach through personal contact networks and improving interpersonal communication skills (Martin, 2009). The third dimension, understanding and delivering customer value, draws on the fact that, without entrepreneurial expertise, managers and entrepreneurs are inclined to rely on generic information, which limits their ability to be innovative and create superior customer value in uncertain environments (Miles et al., 2015).

Entrepreneurial orientation refers to a firm's innovation culture and risk taking attitude. Entrepreneurial orientation has three dimensions: i) propensity for risk taking, 


\section{Entrepreneurial Marketing to Foster Reseller Adoption of Smart Micro-Grid Technology} Hamidreza Kavandi and Mika Westerlund

ii) pro-activeness toward opportunities, and ii) innovativeness (Jones \& Rowley, 2011). Risk taking explains the acceptance of risks to make new opportunities and revolutionary activity (Jones et al., 2013). It shows whether a firm has a tendency for high-risk products and whether risk taking is considered a positive attitude (Ahmadi \& O'Cass, 2015). Subsequently, pro-activeness means the commitment to find new opportunities and cheaper, simpler, or more effective ways of completing tasks (Jones et al., 2013). Whereas innovativeness refers to receptiveness to innovation (Jones \& Rowley, 2011), some definitions emphasize the dualistic nature of innovation in terms of invention and commercialization of that invention (cf. Ahmadi \& O'Cass, 2015). That way, a firm's R\&D aims at inventing new technology and being competitive through rapid commercialization of that technology.

Innovation orientation is associated with creativity in identifying new opportunities and using innovative techniques to solve customer problems (Jones \& Rowley, 2011). Innovation is a marketing-oriented construct that creates an outward-looking focus for all that the company does, and it is central to entrepreneurship as the means by which entrepreneurs can exploit change and provide an opportunity to create businesses (Miles et al., 2015). Innovation orientation also refers to being driven by ideas and intuition as opposed to customer orientation, which is associated with being driven by an assessment of market needs (Morrish, 2011). Innovation orientation has two dimensions: i) knowledge infrastructure and ii) propensity to innovate (Jones et al., 2013). The former means making an infrastructure's knowledge meet formal and informal procedures, practices must be intensive, and data must be gathered and information must be disseminated from inside and using external resources (Jones \& Rowley, 2011). The latter refers to processes for shaping the organization's culture to use and sustain creativity and innovation into all types of processes and services (Jones et al., 2013).

\section{Conceptual Model}

Through this study, we develop a conceptual model with constructs and variables derived from the literature on user adoption and entrepreneurial marketing. This conceptual model (Figure 1) helps to illustrate a number of hypotheses on the relationships between the antecedents of smart micro-grid technology adoption and the reseller's intention to adopt such technology, as well as on the role of vendor's entrepreneurial marketing for reseller's behavioural intention.
Antecedents of smart micro-grid technology adoption (cf. UTAUT/UTAUT2) comprise four independent constructs: effort expectancy and performance expectancy as input/output constructs, and facilitating conditions and price value as contextual constructs. The reseller's behavioural intention to adopt smart micro-grid technology is the dependent construct. Unlike in many previous studies focused on technology adoption, the present model lacks actual behaviour - the actual adoption of the SMG technology - as a dependent construct. It was not included because the literature on technology adoption is unified on the correlation between behavioural intention and actual behaviour, and because the current market adoption rate of the smart microgrid technology is too low (cf. Luthra et al., 2014) to reliably observe actual adoption. Vendor's entrepreneurial marketing, as a moderating factor, consists of three separate yet interrelated constructs: customer orientation, innovation orientation, and entrepreneurial orientation.

The model includes four groups of hypotheses: H1 through $\mathrm{H} 4$ address the direct effects of the antecedents of smart micro-grid adoption to reseller's behavioural intention. Consequently, H5 through H8 suggest the moderating effects of customer orientation, H9 through H12 of innovation orientation, and H13 through H16 of entrepreneurial orientation on the mentioned direct effects. Appendix 1 details the hypotheses.

The model assumes that there are aspects that advance or hinder the adoption of smart micro-grid technology. Smart micro-grid technology offers several benefits: it can provide value in terms of improved efficiency and reliability through advanced real-time control of energy generation and consumption, as well as sustainability through reduced greenhouse gas emissions enabled by the use of cleaner energy sources and better balancing of peaks in electricity consumption (Hashmi, 2011). Conversely, Valocchi, Juliano, and Schurr (2012) list several barriers for the adoption of smart-micro grid technology, including higher price, technology immaturity, lack of suitable infrastructure, integration issues with existing technology, cybersecurity, lack of public awareness, lack of standards, and lack of technical skills. In the absence of a user adoption model for smart micro-grid technology, we took these barriers and benefits into consideration when planning the variables that form the constructs. In addition, variables drawn from end-user adoption models were altered to address the reseller context. 


\section{Entrepreneurial Marketing to Foster Reseller Adoption of Smart Micro-Grid Technology}

Hamidreza Kavandi and Mika Westerlund

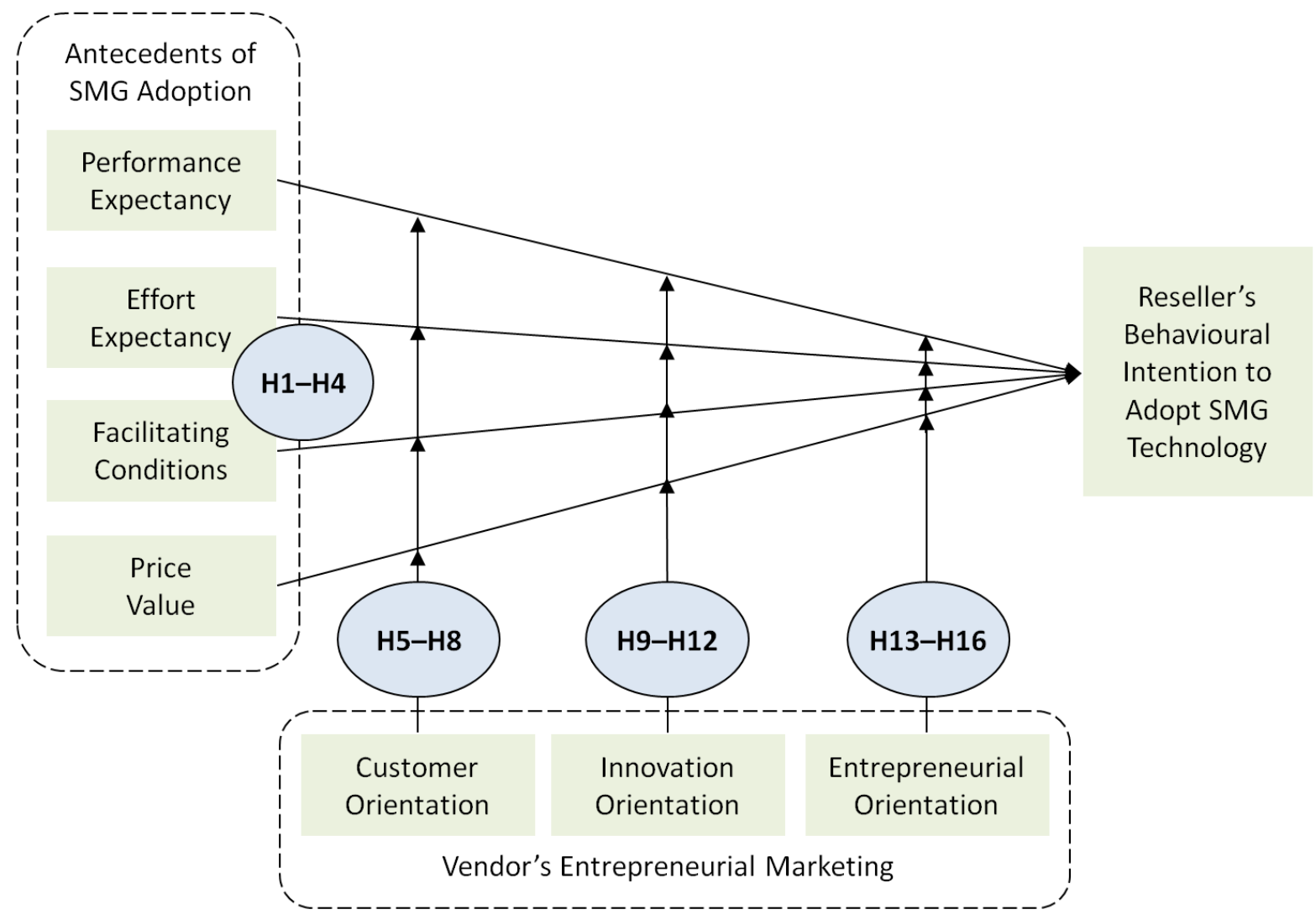

Figure 1. Conceptual model of the use of entrepreneurial marketing to foster reseller adoption of smart micro-grid (SMG) technology, including hypotheses (H1 to H16)

\section{Method}

The design of the empirical research followed three steps: i) semi-structured interviews were conducted with three industry experts in Canada (a sales engineer from a compact substation business, a design engineer from a smart metering technology manufacturer, and a CEO of a solar system company) to explore ideas that could be useful in designing a survey; ii) an online questionnaire was administered to power technology resellers about their adoption of smart micro-grid technology and attitudes on vendor's marketing; and iii) the survey data was analyzed to test the hypotheses and validate the proposed research model. The lead author of this study has worked in the power systems industry for over 13 years, focusing mainly on project management and electrical engineering. A total of 300 contacts in North America, representing industry professionals who work at resellers and have a technical background in power systems, were derived from his LinkedIn account. Responses were received from 107 individuals (36\%) representing executives, entrepren- eurs, sales and customer service staff, and various engineers and maintenance staff. After filtering the responses for completeness, the usable data set consisted of 99 completed questionnaires.

The data were analyzed using the basic partial least squares algorithm from SmartPLS 3.0 software (Ringle et al., 2015) to test the conceptual research model and validate the established hypotheses. The partial least squares technique does not require normalized data and places minimum requirements on measurement levels, unlike many other multivariate modelling approaches (Tenenhaus et al., 2005). Moreover, the partial least squares technique is robust even if there is missing data, and it allows for modelling of multiple relationships simultaneously, easy testing of moderating effects, and effective handling of multicollinearity among constructs (Chin et al., 2003; Haenlein \& Kaplan, 2004). Given that the partial least squares technique is considered appropriate for predictive models such as various adoption models (Teo et al., 2003), it is appropriate for analyzing technology adoption. Finally, be- 


\section{Entrepreneurial Marketing to Foster Reseller Adoption of Smart Micro-Grid Technology Hamidreza Kavandi and Mika Westerlund}

cause our research model includes moderating effects, we verified that our effective sample size of 99 responses was sufficient by following the example of Youssef (2011).

Table 1 shows the internal validity of constructs (see Appendix 2 for details) in terms of average variance extracted (AVE), composite reliability (CR), and Cronbach's Alpha (CA). In order to provide a feasible solution, AVE should be more than .50 (Chou \& Chang, 2008), and CA and CR should each be more than .70 (Hair et al., 2014). All construct values exceed the thresholds, and, thus, they are appropriate for this research. Moreover, Table 1 shows construct correlations; a correlation of more than .60 is a sign of possible bias. Although some of the correlations exceed the value, there are not alarmingly high overlaps, and these conceptually interrelated constructs still measure different qualities. Finally, satisfactory discriminant validity among constructs is obtained when the square root of the average variance (shown as numbers in parentheses) is greater than the corresponding construct correlations.

\section{Results}

When examining the data for the current adoption rate of smart micro-grid technology among resellers, the analysis showed that approximately 50 percent of the respondents attribute less than $5 \%$ of their annual sales to the technology, and such solutions are a significant source of revenue (i.e.. constituting more than half of sales) for only approximately 10 percent of the surveyed resellers. These results confirm that the adoption of smart micro-grid technology is still in its infancy, and that we were justified in excluding actual adoption from the conceptual model and hypotheses. We proceeded with the partial least squares analysis and performed both graph runs for correlation coefficients (ß-values) and bootstrapping procedures (using 500 replications) for statistical significance (T-values) for both the main effects model and the moderated models. Furthermore, we considered both differences in correlation coefficients $(\Delta ß)$ and the coefficients of determination $\left(\Delta R^{2}\right)$ when calculating the effect size $\left(f^{2}\right)$ of each moderating effect, as suggested by Henseler and Fassott (2010).

Figure 2 demonstrates that $\mathrm{H} 1, \mathrm{H} 2, \mathrm{H} 5, \mathrm{H} 6, \mathrm{H} 9$, and H13 are supported by the analysis. After testing all 16 hypotheses, it can be concluded that only 6 hypotheses were supported, and 10 were not. Performance expectancy and effort expectancy have direct and significant effects (T-value $>1.96$ ) on behavioral intention. Whereas performance expectancy increases the probability of SMG adoption, effort expectancy decreases the likelihood. Unexpectedly, facilitating conditions and price value were not associated with reseller's intention to adopt SMG technology. As to moderating effects, custom-

Table 1. Internal validity and construct correlations

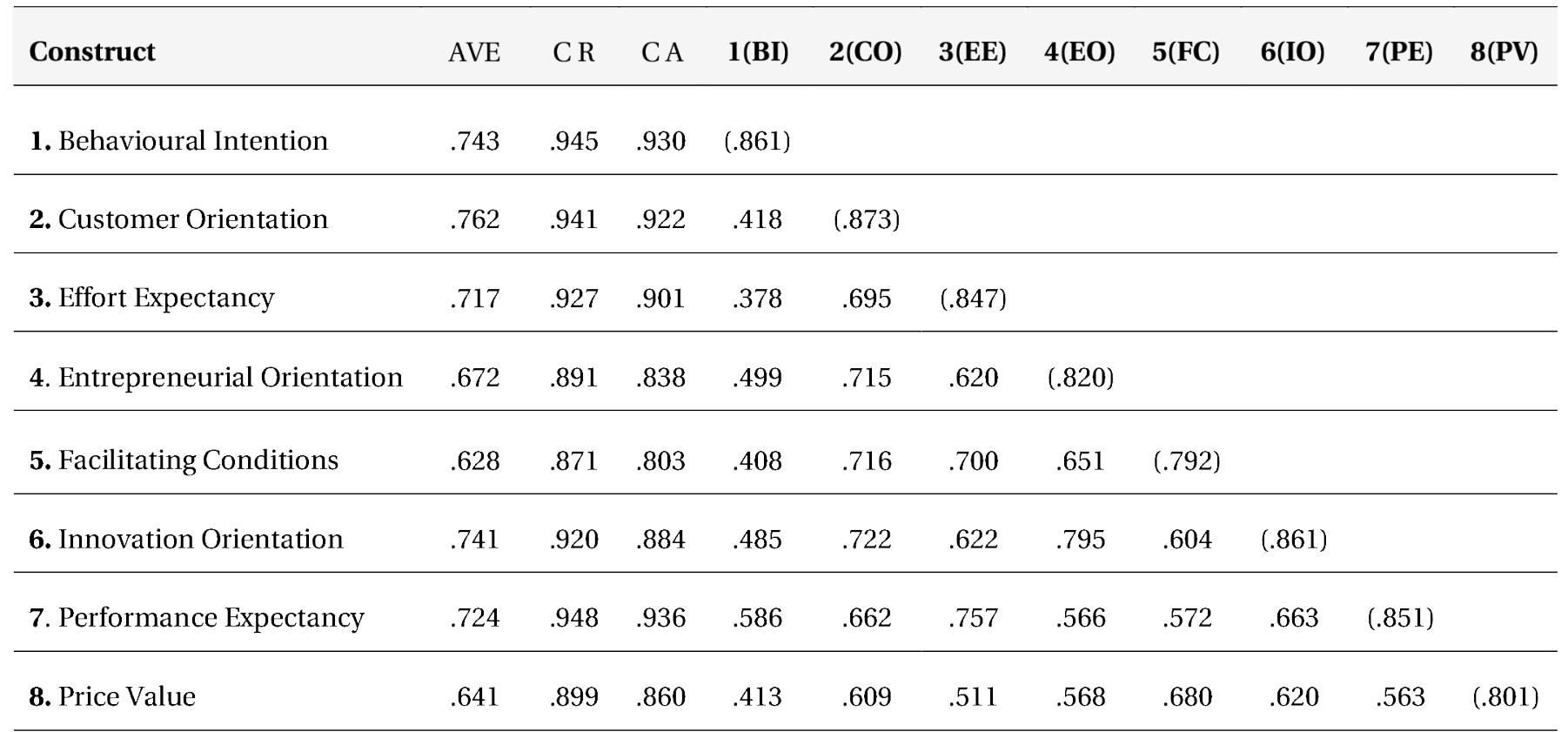




\section{Entrepreneurial Marketing to Foster Reseller Adoption of Smart Micro-Grid Technology}

Hamidreza Kavandi and Mika Westerlund

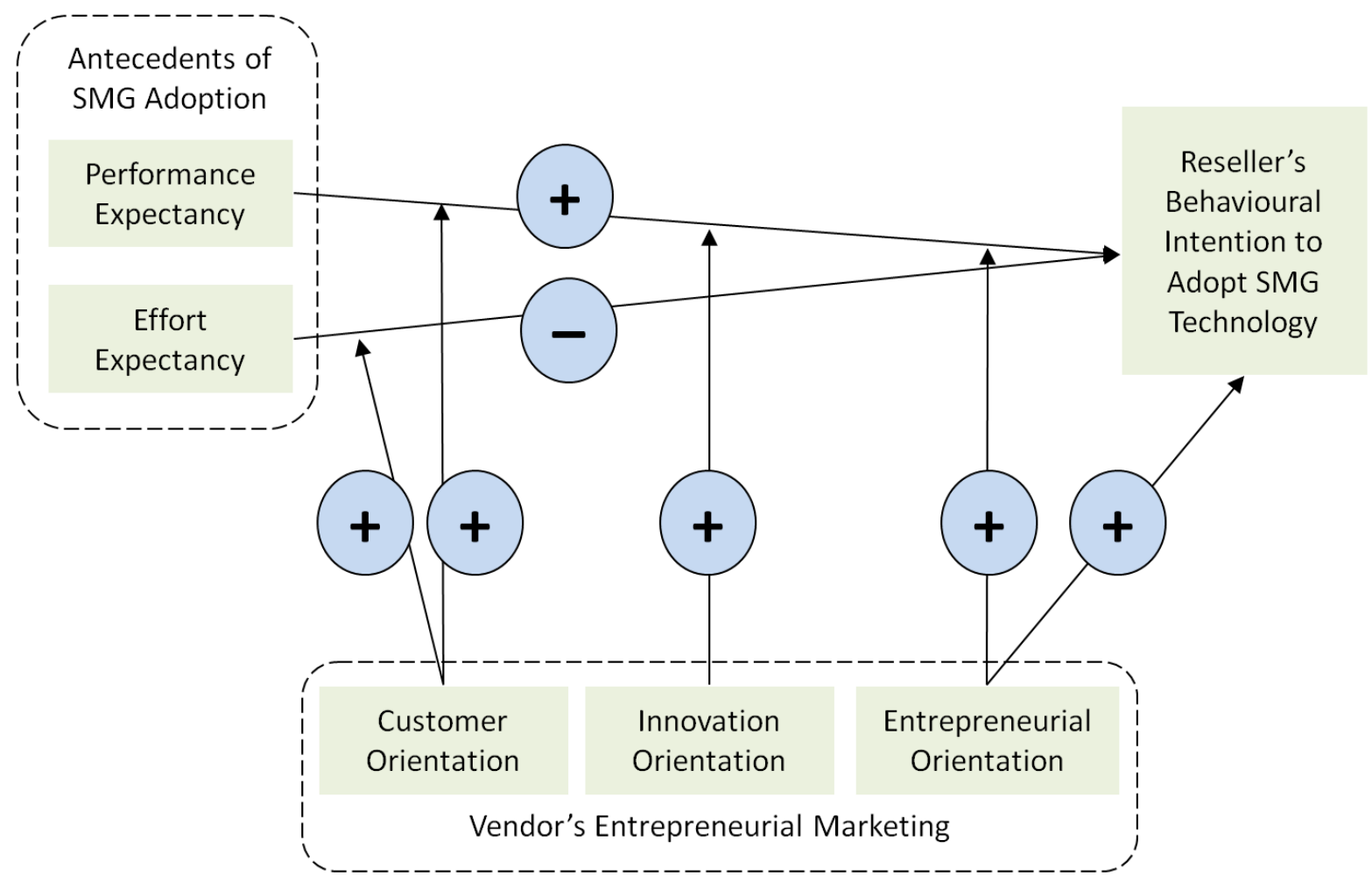

Figure 2. The final model with validated hypotheses

er orientation strengthens both the effects of performance expectancy and effort expectancy on behavioral intension. Moreover, both innovation orientation and entrepreneurial orientation increase the effect of performance expectancy on behavioral intention. Finally, a secondary finding from the analysis was that entrepreneurial orientation has a direct effect on reseller's behavioral intention. In all, the model explains approximately $40 \%$ of the variance (Adj. R2) in the independent construct.

\section{Conclusion}

This study focused on understanding the role of vendor's entrepreneurial marketing in the adoption of smart micro-grid technology by resellers. The endeavour is of importance because smart micro-grid technology has not yet been widely adopted in the market despite of the value it can provide, and because resellers play important roles as distribution channel members in the market diffusion of new technology. Despite the limitations of our research - the focus on power systems resellers in North America only and the lack of previously validated reseller adoption models the results from our empirical analysis point out what factors influence the adoption of smart micro-grid technology by resellers and what barriers must be removed. Thus, the results can be used as a guideline for developing strategies to encourage reseller adoption of novel smart micro-grid solutions.

The results show that performance expectancy increases reseller's behavioural intention to adopt smart micro-grid technology whereas effort expectancy decreases the intention. Moreover, the vendor's entrepreneurial marketing in terms of customer orientation moderates both of these relationships. In other words, customer orientation advances the intention of resellers to adopt novel technology. In addition, both innovation orientation and entrepreneurial orientation moderate the relationship between performance expectancy and behavioural intention, thereby helping resellers to adopt the technology. Surprisingly, the study also found that the vendor's entrepreneurial orientation has a direct positive effect on the reseller's intention to adopt smart micro-grid technology. Previous literature on user adoption shows that behavioural intention predicts actual behaviour (i.e., the likelihood of a reseller buying, modifying, and reselling a vendor's smart micro-grid technology). 


\section{Entrepreneurial Marketing to Foster Reseller Adoption of Smart Micro-Grid Technology} Hamidreza Kavandi and Mika Westerlund

These results contribute to the existing theory of user adoption. The main implications include: i) the limited applicability of the user adoption models in the reseller context and ii) the importance of vendor's entrepreneurial marketing for the adoption of novel technology by resellers. First, it is obvious that existing technology adoption and user adoption models are only partially applicable in the reseller context. Although they have been widely used over the past decades to understand the spread of new technology on the market (cf. Venkatesh et al., 2012), the strict focus on the end user has neglected resellers as agents in the diffusion. Although resellers may also be end users of the novel technology, the motivation of a reseller to engage in technology is likely different. Hence, future research should focus on developing reseller adoption models that focus on the input/output of functional value (e.g., how to make more money and differentiate from the competitors by selling a specific technology) rather than the use value (e.g., how to benefit from implementing and using a specific technology). Second, a vendor's proactive channel marketing seems to have major effect on why resellers adopt and stock novel technology. The results reinforce similar findings from other contexts (cf. Westerlund \& Rajala, 2014) and suggest that research should pay more attention to channel marketing instead of looking only at the end-user part.

The findings are also interesting from the practice point of view, as improving the input/output ratio expected by the reseller may significantly promote their adoption of smart micro-grid technology. In more detail, performance expectancy is the main driver of reseller adoption, and a vendor's entrepreneurial marketing amplifies the importance of that specific driver. Moreover, the fact that facilitating conditions or price value were not significant factors reflects the lack of awareness and understanding of smart micro-grid technology among power systems resellers. Thus, vendors need to address the vendor-reseller relationship, the benefits of new technological solutions, and entrepreneurial marketing strategies when planning their marketing activity and subsequent marketing messages aimed at power systems resellers. Vendors can foster the adoption of smart micro-grid technology among their resellers by offering more information, extended support, better incentives, and by creating trust in the vendor-reseller relationship.

\section{About the Authors}

Hamidreza Kavandi, MASc, MSc, is a graduate of the Technology Innovation Management program at Carleton University in Ottawa, Canada. Hamid earned his first master's degree in Electrical Engineering (power systems) from the Iran University of Science and Technology in Tehran. His current research interests include entrepreneurial marketing, business strategy, and business and management models in restructured power systems.

Mika Westerlund, DSc (Econ), is an Associate Professor at Carleton University in Ottawa, Canada. He previously held positions as a Postdoctoral Scholar in the Haas School of Business at the University of California Berkeley and in the School of Economics at Aalto University in Helsinki, Finland. Mika earned his doctoral degree in Marketing from the Helsinki School of Economics in Finland. His current research interests include open and user innovation, the Internet of Things, business strategy, and management models in high-tech and service-intensive industries.

\section{References}

Ahmadi, H., \& O'Cass, A. 2015. The Role of Entrepreneurial Marketing in New Technology Ventures First Product Commercialization. Journal of Strategic Marketing.

http://dx.doi.org/10.1080/0965254X.2015.1035039

Becherer, R. C., Haynes, P. J., \& Helms, M. M. 2008. An Exploratory Investigation of Entrepreneurial Marketing in SMEs: The Influence of Owner/Operator. Journal of Business and Entrepreneurship, 20(2): 44-63.

Benbasat, I., \& Barki, H. 2007. Quo vadis, TAM? Journal of the Association of Information Systems, 8(4): 211-218.

Cardenas, J., Gemoets, L., Rosas, J., A., \& Sarfi, R. 2014. A Literature Survey on Smart Grid Distribution: An Analytical Approach. Journal of Cleaner Production, 65: 202-216. http://dx.doi.org/10.1016/j.jclepro.2013.09.019

Chin, W. W., Marcolin, B. L., \& Newsted, P. R. 2003. A Partial Least Squares Latent Variable Modeling Approach for Measuring Interaction Effects: Results from a Monte Carlo Simulation Study and an Electronic-Mail Emotion/Adoption Study. Information Systems Research, 14(2): 189-217.

http://dx.doi.org/10.1287/isre.14.2.189.16018

Chou, S. W., \& Chang, Y. C. 2008. The Implementation Factors That Influence the ERP (Enterprise Resource Planning) Benefits. Decision Support System, 46(1): 149-157.

http://dx.doi.org/10.1016/j.dss.2008.06.003 


\section{Entrepreneurial Marketing to Foster Reseller Adoption of Smart Micro-Grid Technology Hamidreza Kavandi and Mika Westerlund}

Chung, C., Chatterjee, S. C., \& Sengupta, S. 2012. Manufacturers' Reliance on Channel Intermediaries: Value Drivers in the Presence of a Direct Web Channel. Industrial Marketing Management, 41(1): $40-53$.

http://dx.doi.org/10.1016/j.indmarman.2011.11.010

Collinson, E. \& Shaw, E. 2001. Entrepreneurial Marketing - A Historical Perspective on Development and Practice. Management Decision, 39(9): 761-766. http://dx.doi.org/10.1108/EUM0000000006221

Davis, F. D. 1989. Perceived Usefulness, Perceived Ease of Use, and User Acceptance of Information Technology. MIS Quarterly, 13(3): 319-340. http://dx.doi.org/10.2307\%2F249008

Fang, X., Misra, S., Xue, G., \& Yang, D. 2012. Smart Grid - The New and Improved Power Grid: A Survey. IEEE Communication Surveys \& Tutorials, 14(4): 944-978. http://dx.doi.org/10.1109/SURV.2011.101911.00087

Fillis, I. 2010. The Art of the Entrepreneurial Marketer. Journal of Research in Marketing and Entrepreneurship, 12(2): 87-107. http://dx.doi.org/10.1108/14715201011090576

Franco, M., Santos, M. F., Ramalho, I., \& Nunes, C. 2014. An Exploratory Study of Entrepreneurial Marketing in SMEs. Journal of Small Business and Enterprise Development, 21(2): 265-283. http://dx.doi.org/10.1108/JSBED-10-2012-0112

Giordano, V., \& Fulli, G. 2012. A Business Case for Smart Grid Technology: A Systemic Perspective. Energy Policy, 40: 252-259. http://dx.doi.org/10.1016/j.enpol.2011.09.066

Hair Jr, J. F., Sarstedt M., Hopkins, L., \& Kuppelwieser, V. 2014. Partial Least Squares Structural Equation Modeling (PLS-SEM) an Emerging Tool in Business Research. European Business Review, 26(2): 106-121.

http://dx.doi.org/10.1108/EBR-10-2013-0128

Hashmi, M. 2011. Survey of Smart Grids Concepts Worldwide. VTT Working Papers 166.

http://www.vtt.fi/inf/pdf/workingpapers/2011/W166.pdf

Haenlein, M., \& Kaplan, A. M. 2004. A Beginner's Guide to Partial Least Squares Analysis. Understanding Statistics, 3(4): 283-297. http://dx.doi.org/10.1207/s15328031us0304_4

Henseler, J., \& Fassott, G. 2010. Testing Moderating Effects in PLS Path Models: An Illustration of Available Procedures. In V. Esposito Vinzi, W. W. Chin, J. Henseler, \& H. Wang (Eds.), Handbook of Partial Least Squares: Concepts, Methods and Applications (Springer Handbooks of Computational Statistics Series, vol. II): 713-735. Heidelberg, Dordrecht, London, New York: Springer.

http://dx.doi.org/10.1007/978-3-540-32827-8_31

Hills, G. E., Hultman, C. M., \& Miles, M. P. 2008. The Evolution and Development of Entrepreneurial Marketing. Journal of Small Business Management, 46(1): 99-112.

Hills, G. E., \& Hultman, C. M. 2011. Academic Roots: The Past and Present of Entrepreneurial Marketing. Journal of Small Business and Entrepreneurship, 24(1): 1-10.

http://dx.doi.org/10.1080/08276331.2011.10593521

Jones, R., \& Rowley, J. 2011. Entrepreneurial Marketing in Small Businesses: A Conceptual Exploration. International Small Business Journal, 29(1): 25-36.

http://dx.doi.org/10.1177/0266242610369743
Jones, R., Suoranta, M., \& Rowley, J. 2013. Entrepreneurial Marketing: A Comparative Study. The Service Industries Journal, 33(7-8): 705-719.

http://dx.doi.org/10.1080/02642069.2013.740470

Lowry, P. B., \& Gaskin, J. 2014. Partial Least Squares (PLS) Structural Equation Modeling (SEM) for Building and Testing Behavioral Causal Theory: When to Choose It and How to Use It. IEEE Transactions on Professional Communication, 57(2): 123-146. http://dx.doi.org/10.1109/TPC.2014.2312452

Luthra, S., Kumar, S., Kharb, R., Ansari, M. F., \& Shimmi, S. L. 2014. Adoption of Smart Grid Technologies: An Analysis of Interactions among Barriers. Renewable and Sustainable Energy Reviews, 33: $554-565$.

http://dx.doi.org/10.1016/j.rser.2014.02.030

Martin, D. M. 2009. The Entrepreneurial Marketing Mix. Qualitative Market Research: An International Journal, 12(4): 391-403. http://dx.doi.org/10.1108/13522750910993310

Miles, M., Gilmore, A., Harrigan, P., Lewis, G., \& Sethna, Z. 2015. Exploring Entrepreneurial Marketing. Journal of Strategic Marketing, 23(2): 94-111. http://dx.doi.org/10.1080/0965254X.2014.914069

Morris, M. H., Schindehutte, M., \& LaForge, R. D. 2002. Entrepreneurial Marketing: A Construct for Integrating Emerging Entrepreneurship and Marketing Perspectives. Journal of Marketing Theory and Practice, 10(4): 1-19. http://www.jstor.org/stable/41304278

Morrish, S. C. 2011. Entrepreneurial Marketing: A Strategy for the Twenty-First Century? Journal of Research in Marketing and Entrepreneurship, 13(2): 110-119. http://dx.doi.org/10.1108/14715201111176390

Mort, G. S., Weerawardena, J., \& Liesch, P. 2012. Advancing Entrepreneurial Marketing Evidence from Born Global Firms. European Journal of Marketing, 46(3/4): 542-561. http://dx.doi.org/10.1108/03090561211202602

Osmonbekov, T. 2010. Reseller Adoption of Manufacturers' eBusiness Tools: The Impact of Social Enforcement, Technology-Relationship Fit and the Mediating Role of Reseller Benefits. Journal of Business Strategy, 63(3): 217-223. http://dx.doi.org/10.1016/j.jbusres.2009.01.012

Ozaki, R. 2009. Adopting Sustainable Innovation: What Makes Consumers Sign up to Green Electricity? Business Strategy and the Environment, 20(1): 1-17. http://dx.doi.org/10.1002/bse.650

Teo, H. H., Kwok, K. W., \& Benbasat, I. 2003. Predicting Intention to Adopt Interorganizational Linkages: An Institutional Perspective. MIS Quarterly, 27(1): 19-49.

Tenenhaus, M., Vinzi, V. E., Chatelin, Y.-M., \& Lauro, C. 2005. PLS Path Modeling. Computational Statistics and Data Analysis, 48(1): 159-205.

http://dx.doi.org/10.1016/j.csda.2004.03.005

Ringle, C. M., Wende, S., \& Becker, J.-M. 2015. SmartPLS 3. SmartPLS $\mathrm{GmbH}$ : Boenningstedt. http://www.smartpls.com

Saxena, A. 2014. Smart Grid Technology. Progress in Science in Engineering Research Journal, 12(2): 265-273. 


\section{Entrepreneurial Marketing to Foster Reseller Adoption of Smart Micro-Grid Technology Hamidreza Kavandi and Mika Westerlund}

Sreenivas, M., \& Srinivas, T. 2008. Effectiveness of Distribution Network. International Journal of Information Systems and Supply Chain Management, 1(1): 80-86.

http://dx.doi.org/10.4018/jisscm.2008010105

Valocchi, M., Juliano, J., \& Schurr, A. 2012. Evolution: Smart Grid Technology Requires Creating New Business Models. Reinventing Energy, 62-67.

Venkatesh, V., Morris, M., \& Davis, F. 2003. User Acceptance of Information Technology: Toward a Unified View. MIS Quarterly, 27(3): 425-478.
Venkatesh, V., Thong, J. Y., \& Xu, X. 2012. Consumer Acceptance and Use of Information Technology: Extending the Unified Theory of Acceptance and Use of Technology. MIS Quarterly, 36(1): 157-178.

Westerlund, M., \& Rajala, R. 2014. Effective Digital Channel Marketing for Cybersecurity Solutions. Technology Innovation Management Review, 4(10): 22-32.

http://timreview.ca/article/836

Youssef, M. A. F. M. 2011. Effective Sample Size Calculation: How Many Patients Will I Need to Include in My Study? Middle East Fertility Society Journal, 16(4): 295-296. http://dx.doi.org/10.1016/j.mefs.2011.10.001

Citation: Kavandi, H., \& Westerlund, M. 2015. Using Entrepreneurial Marketing to Foster Reseller Adoption of Smart Micro-Grid Technology.

Technology Innovation Management Review, 5(9): 5-16. http://timreview.ca/article/925

Keywords: entrepreneurial marketing, technology adoption, power systems, smart micro-grids, resellers 


\section{Entrepreneurial Marketing to Foster Reseller Adoption of Smart Micro-Grid Technology Hamidreza Kavandi and Mika Westerlund}

\section{Appendix 1. Hypotheses}

\begin{tabular}{|c|c|c|c|c|}
\hline Hypothesis & $\begin{array}{l}\text { Dependent } \\
\text { Variable }\end{array}$ & $\begin{array}{l}\text { Independent } \\
\text { Variable }\end{array}$ & Moderator & Explanation \\
\hline H1 & $\begin{array}{l}\text { Behavioural } \\
\text { intention }\end{array}$ & $\begin{array}{l}\text { Performance } \\
\text { expectancy }\end{array}$ & $\mathrm{N} / \mathrm{A}$ & $\begin{array}{l}\text { Performance expectancy has a positive effect on behavioural } \\
\text { intention. }\end{array}$ \\
\hline H2 & $\begin{array}{l}\text { Behavioural } \\
\text { intention }\end{array}$ & $\begin{array}{l}\text { Effort } \\
\text { expectancy }\end{array}$ & N/A & $\begin{array}{l}\text { Effort expectancy has a positive effect on behavioural } \\
\text { intention. }\end{array}$ \\
\hline H3 & $\begin{array}{l}\text { Behavioural } \\
\text { intention }\end{array}$ & $\begin{array}{l}\text { Facilitating } \\
\text { conditions }\end{array}$ & N/A & $\begin{array}{l}\text { Facilitating conditions has a positive effect on behavioural } \\
\text { intention. }\end{array}$ \\
\hline $\mathbf{H 4}$ & $\begin{array}{l}\text { Behavioural } \\
\text { intention }\end{array}$ & Price value & N/A & Price value has a positive effect on behavioural intention. \\
\hline H5 & $\begin{array}{l}\text { Behavioural } \\
\text { intention }\end{array}$ & $\begin{array}{l}\text { Performance } \\
\text { expectancy }\end{array}$ & $\begin{array}{l}\text { Customer } \\
\text { orientation }\end{array}$ & $\begin{array}{l}\text { The influence of performance expectancy on behavioural } \\
\text { intention is positively moderated by customer orientation. }\end{array}$ \\
\hline H6 & $\begin{array}{l}\text { Behavioural } \\
\text { intention }\end{array}$ & $\begin{array}{l}\text { Effort } \\
\text { expectancy }\end{array}$ & $\begin{array}{l}\text { Customer } \\
\text { orientation }\end{array}$ & $\begin{array}{l}\text { The influence of effort expectancy on behavioural intention is } \\
\text { positively moderated by customer orientation. }\end{array}$ \\
\hline H7 & $\begin{array}{l}\text { Behavioural } \\
\text { intention }\end{array}$ & $\begin{array}{l}\text { Facilitating } \\
\text { conditions }\end{array}$ & $\begin{array}{l}\text { Customer } \\
\text { orientation }\end{array}$ & $\begin{array}{l}\text { The influence of facilitating conditions on behavioural } \\
\text { intention is positively moderated by customer orientation. }\end{array}$ \\
\hline H8 & $\begin{array}{l}\text { Behavioural } \\
\text { intention }\end{array}$ & Price value & $\begin{array}{l}\text { Customer } \\
\text { orientation }\end{array}$ & $\begin{array}{l}\text { The influence of price value on behavioural intention is } \\
\text { positively moderated by customer orientation. }\end{array}$ \\
\hline H9 & $\begin{array}{l}\text { Behavioural } \\
\text { intention }\end{array}$ & $\begin{array}{l}\text { Performance } \\
\text { expectancy }\end{array}$ & $\begin{array}{l}\text { Innovation } \\
\text { orientation }\end{array}$ & $\begin{array}{l}\text { The influence of performance expectancy on behavioural } \\
\text { intention is positively moderated by innovation orientation. }\end{array}$ \\
\hline H10 & $\begin{array}{l}\text { Behavioural } \\
\text { intention }\end{array}$ & $\begin{array}{l}\text { Effort } \\
\text { expectancy }\end{array}$ & $\begin{array}{l}\text { Innovation } \\
\text { orientation }\end{array}$ & $\begin{array}{l}\text { The influence effort expectancy on behavioural intention is } \\
\text { positively moderated by innovation orientation. }\end{array}$ \\
\hline H11 & $\begin{array}{l}\text { Behavioural } \\
\text { intention }\end{array}$ & $\begin{array}{l}\text { Facilitating } \\
\text { conditions }\end{array}$ & $\begin{array}{l}\text { Innovation } \\
\text { orientation }\end{array}$ & $\begin{array}{l}\text { The influence of facilitating conditions on behavioural } \\
\text { intention is positively moderated by innovation orientation. }\end{array}$ \\
\hline $\mathrm{H} 12$ & $\begin{array}{l}\text { Behavioural } \\
\text { intention }\end{array}$ & Price value & $\begin{array}{l}\text { Innovation } \\
\text { orientation }\end{array}$ & $\begin{array}{l}\text { The influence of price value on behavioural intention is } \\
\text { positively moderated by innovation orientation. }\end{array}$ \\
\hline H13 & $\begin{array}{l}\text { Behavioural } \\
\text { intention }\end{array}$ & $\begin{array}{l}\text { Performance } \\
\text { expectancy }\end{array}$ & $\begin{array}{l}\text { Entrepreneurial } \\
\text { orientation }\end{array}$ & $\begin{array}{l}\text { The influence of performance expectancy on behavioural } \\
\text { intention is positively moderated by entrepreneurial } \\
\text { orientation. }\end{array}$ \\
\hline H14 & $\begin{array}{l}\text { Behavioural } \\
\text { intention }\end{array}$ & $\begin{array}{l}\text { Effort } \\
\text { expectancy }\end{array}$ & $\begin{array}{l}\text { Entrepreneurial } \\
\text { orientation }\end{array}$ & $\begin{array}{l}\text { The influence of effort expectancy on behavioural intention is } \\
\text { positively moderated by entrepreneurial orientation. }\end{array}$ \\
\hline H15 & $\begin{array}{l}\text { Behavioural } \\
\text { intention }\end{array}$ & $\begin{array}{l}\text { Facilitating } \\
\text { conditions }\end{array}$ & $\begin{array}{l}\text { Entrepreneurial } \\
\text { orientation }\end{array}$ & $\begin{array}{l}\text { The influence of facilitating conditions on behavioural } \\
\text { intention is positively moderated by entrepreneurial } \\
\text { orientation. }\end{array}$ \\
\hline H16 & $\begin{array}{l}\text { Behavioural } \\
\text { intention }\end{array}$ & Price value & $\begin{array}{l}\text { Entrepreneurial } \\
\text { orientation }\end{array}$ & $\begin{array}{l}\text { The influence of price value on behavioural intention is } \\
\text { positively moderated by entrepreneurial orientation. }\end{array}$ \\
\hline
\end{tabular}




\section{Entrepreneurial Marketing to Foster Reseller Adoption of Smart Micro-Grid Technology Hamidreza Kavandi and Mika Westerlund}

Appendix 2. Details of internal validity of constructs

\begin{tabular}{|c|c|c|c|c|}
\hline & Item & Loading & Weight & Item description \\
\hline \multirow{6}{*}{$\begin{array}{l}\text { Behavioural } \\
\text { Intention }\end{array}$} & BI1 & .886 & .190 & Reselling SMG solutions is a really good opportunity for my business. \\
\hline & BI2 & .926 & .201 & Reselling SMG solutions is a really wise idea for my business. \\
\hline & BI3 & .813 & .189 & Reselling SMG solutions provides the best opportunity to enhance my business. \\
\hline & BI4 & .835 & .211 & Reselling SMG solutions is promoting my business. \\
\hline & BI6 & .868 & .187 & Reselling SMG solutions corresponds well with my business content. \\
\hline & BI7 & .837 & .183 & Reselling SMG solutions is pleasant for my business. \\
\hline \multirow{5}{*}{$\begin{array}{l}\text { Customer } \\
\text { Orientation }\end{array}$} & $\mathrm{CO2}$ & .877 & .254 & Communication with customers is strongly valued in my business. \\
\hline & $\mathrm{CO3}$ & .923 & .258 & Understanding and delivering customer value have a highly positive impact on my business. \\
\hline & $\mathrm{CO4}$ & .834 & .180 & The ability to react to customer needs quickly has a very strong impact on reselling SMG solutions. \\
\hline & CO6 & .869 & .206 & $\begin{array}{l}\text { The adoption of customer satisfaction perspective has a strong impact on SMG solution retail } \\
\text { business. }\end{array}$ \\
\hline & $\mathrm{CO7}$ & .861 & .244 & $\begin{array}{l}\text { Understanding customer needs and adapting the seller's response to satisfy those needs are crucial } \\
\text { for the success. }\end{array}$ \\
\hline \multirow{5}{*}{$\begin{array}{l}\text { Effort } \\
\text { Expectancy }\end{array}$} & EE2 & .876 & .196 & Prefer reselling SMG solutions that are easy to learn to operate. \\
\hline & EE3 & .877 & .239 & Prefer reselling SMG solutions that are easy to use. \\
\hline & EE4 & .825 & .250 & $\begin{array}{l}\text { Prefer reselling SMG solutions that promote clear and understandable interaction with the } \\
\text { supplier. }\end{array}$ \\
\hline & EE5 & .823 & .268 & Prefer reselling more flexible and interactive SMG solutions \\
\hline & EE7 & .831 & .231 & Prefer reselling SMG solutions that require little time in doing operational tasks. \\
\hline \multirow{4}{*}{$\begin{array}{l}\text { Entrepreneurial } \\
\text { Orientation }\end{array}$} & EO2 & .782 & .247 & Would put more effort in reselling SMG solutions if the supplier responded to my inquiry quickly. \\
\hline & EO4 & .822 & .303 & Would put more effort in reselling SMG solutions if I had pro-active support from the supplier. \\
\hline & E06 & .874 & .321 & $\begin{array}{l}\text { Would put more effort in reselling SMG solutions if the supplier emphasized the development of } \\
\text { new and innovative products. }\end{array}$ \\
\hline & EO7 & .797 & .347 & $\begin{array}{l}\text { Would put more effort in reselling SMG solutions if my business was asked to introduce new } \\
\text { products/services or administrative or operational techniques. }\end{array}$ \\
\hline \multirow{4}{*}{$\begin{array}{l}\text { Facilitating } \\
\text { Condition }\end{array}$} & FC4 & .762 & .311 & Prefer reselling SMG solutions that are compatible with other systems that my business sells. \\
\hline & FC5 & .786 & .296 & Prefer reselling SMG solutions that have guidance available for my business. \\
\hline & FC6 & .813 & .295 & Prefer reselling SMG solutions that have specialized instructions available for my business. \\
\hline & FC7 & .806 & .360 & $\begin{array}{l}\text { Prefer reselling SMG solutions that have specific person or technical group available for assistance } \\
\text { with system difficulties. }\end{array}$ \\
\hline \multirow{4}{*}{$\begin{array}{l}\text { Innovation } \\
\text { Orientation }\end{array}$} & IO4 & .859 & .312 & Would put more effort in reselling SMG solution if the supplier supported sustaining innovation \\
\hline & IO5 & .852 & .252 & $\begin{array}{l}\text { Would put more effort in reselling SMG technology if the supplier identified new opportunities for } \\
\text { my business. }\end{array}$ \\
\hline & 106 & .854 & .260 & $\begin{array}{l}\text { Would put more effort in reselling SMG solutions if the supplier supported my innovation and } \\
\text { application of SMG solutions. }\end{array}$ \\
\hline & 107 & .880 & .336 & $\begin{array}{l}\text { Would put more effort in reselling SMG solutions if they converted opportunities into concrete, } \\
\text { workable, and marketable ideas. }\end{array}$ \\
\hline \multirow{7}{*}{$\begin{array}{l}\text { Performance } \\
\text { Expectancy }\end{array}$} & PE1 & .890 & .209 & Prefer reselling SMG solutions that will improve my business performance. \\
\hline & PE2 & .901 & .194 & Prefer reselling SMG solutions that will increase my business productivity. \\
\hline & PE3 & .914 & .188 & Prefer reselling SMG solutions that will enhance the effectiveness in my business. \\
\hline & PE4 & .833 & .173 & Prefer reselling SMG solutions that enable me to reach my business goals more quickly. \\
\hline & PE5 & .859 & .161 & $\begin{array}{l}\text { Prefer reselling SMG solutions that provide me with valuable information from the perspective of } \\
\text { business. }\end{array}$ \\
\hline & PE6 & .758 & .138 & Prefer reselling SMG solutions that will increase my business output for the same amount of effort. \\
\hline & PE7 & .787 & .102 & Prefer reselling SMG solutions that will increase my chances of obtaining business benefits. \\
\hline \multirow{5}{*}{ Price Value } & PV1 & .796 & .242 & $\begin{array}{l}\text { Prefer reselling SMG solutions whose high price/value ratio makes an important benefit for my } \\
\text { business against competitors. }\end{array}$ \\
\hline & PV2 & .828 & .204 & $\begin{array}{l}\text { Prefer reselling SMG solutions that are superior in bearing the monetary cost of use compared to } \\
\text { regular systems. }\end{array}$ \\
\hline & PV3 & .858 & .278 & High price/value ratio of a SMG solution has a positive effect on my business as a reseller. \\
\hline & PV4 & .756 & .258 & $\begin{array}{l}\text { Prefer reselling SMG technology with a high price/value ratio, because I think it can act as a } \\
\text { predictor of customer's behaviour. }\end{array}$ \\
\hline & PV7 & .762 & .269 & $\begin{array}{l}\text { Prefer reselling SMG technology that has a balanced tradeoff between the perceived benefits and } \\
\text { the monetary cost of using it. }\end{array}$ \\
\hline
\end{tabular}

